\title{
Two novel psychrotolerant species, Bacillus psychrotolerans sp. nov. and Bacillus psychrodurans sp. nov., which contain ornithine in their cell walls
}

DSMZ-Deutsche Sammlung von Mikroorganismen und Zellkulturen $\mathrm{GmbH}$, Mascheroder Weg $1 \mathrm{~b}$, 38124 Braunschweig, Germany

\author{
Hussein A. Abd El-Rahman, † Dagmar Fritze, Cathrin Spröer \\ and Dieter Claus $\ddagger$
}

\begin{abstract}
Author for correspondence: Dagmar Fritze. Tel: +495312616 254. Fax: +49 5312616418. e-mail: dfr@dsmz.de
\end{abstract}

\begin{abstract}
Eleven psychrotolerant Bacillus strains with ornithine as diamino acid in position 3 of the peptide side chain of the cell wall and a G+C range of 35.7-38.4 mol\% were characterized taxonomically. DNA-DNA hybridization studies confirmed previously physiologically established groups. High DNAbinding values $(>70 \%)$ were found within groups I A (consisting of the type strain of Bacillus insolitus DSM $5^{\top}$ and Bacillus insolitus DSM 2272), I B (consisting of isolates 3H1 $, 71 \mathrm{H1}, 84 \mathrm{E1}, 87 \mathrm{H2}$ and $4 \mathrm{H2}$ ) and I C (consisting of isolates 68E3', 61E1, 4E3 and 67E1). Low DNA-binding values $(<60 \%)$ were revealed between the three groups. Consequently, strains of groups I B and I C were considered as being representatives of new psychrotolerant species. For group I B strains the name Bacillus psychrotolerans sp. nov. is proposed with

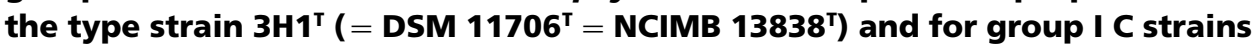
the name Bacillus psychrodurans sp. nov. is proposed with the type strain 68E3 $^{\top}$ ( = DSM $11713^{\top}=$ NCIMB $^{13837^{\top}}$ ).
\end{abstract}

Keywords: psychrotolerant, Bacillus, ornithine

\section{INTRODUCTION}

Six psychrotolerant or psychrophilic Bacillus species have been described to date: Bacillus globisporus (Larkin \& Stokes, 1967; Rüger \& Richter, 1979; Nakamura, 1984), Bacillus insolitus (Larkin \& Stokes, 1967), Bacillus macquariensis (now Paenibacillus macquariensis) (Ash et al., 1993; Marshall \& Ohye, 1966), Bacillus marinus (Rüger, 1983; Rüger et al., 2000), Bacillus psychrophilus (Rüger \& Richter, 1979; Larkin \& Stokes, 1967; Nakamura, 1984) and Bacillus

Published online ahead of print on 16 May 2002 as DOI 10.1099/ ijs.0.01665-0.

tPresent address: Ain-Shams University, Faculty of Agriculture, Food Science Department, PO Box 68, 11241 Hadyek Shoubra, Cairo, Egypt.

$\ddagger$ Present address: Chemnitzer Str. 3, 37085 Göttingen, Germany.

Abbreviation: CASO agar, casein-peptone soymeal-peptone agar.

The EMBL accession numbers for the 16S rDNA gene sequences of strains $3 \mathrm{H} 1^{\top}$ (DSM $11706^{\top}$ ) and $68 \mathrm{E}^{\top}$ (DSM $11713^{\top}$ ) are AJ277983 and AJ277984, respectively. psychrosaccharolyticus (Larkin \& Stokes, 1967; Priest et al., 1988).

To date, the taxonomy of psychrotolerant and psychrophilic Bacillus strains is somewhat uncertain as it is based on only a few strains and a few discriminating properties. However, studies on the $16 \mathrm{~S}$ rRNA sequences as well as DNA-DNA hybridizations, including the type strains of these species (Stackebrandt et al., 1987; Ash et al., 1991; Fox et al., 1992; Farrow et al., 1994), confirmed the individual species position of Bacillus globisporus, Bacillus insolitus, Bacillus macquariensis (now Paenibacillus macquariensis), Bacillus psychrophilus and Bacillus psychrosaccharolyticus. Rüger et al. (2000) have provided an emended description of Bacillus marinus. Bacillus marinus has recently been reclassified as Marinibacillus marinus (Yoon et al., 2001b), and Bacillus globisporus, Bacillus psychrophilus and Bacillus pasteurii have been transferred to Sporosarcina (Yoon et al., 2001a).

In a previous study (Abd El-Rahman, 1988) a large number of psychrotolerant Bacillus isolates were sub- 
jected to various tests to reveal their morphological, physiological, biochemical and genetic properties. Fourteen reference strains of the species Bacillus globisporus, Bacillus insolitus, Bacillus psychrophilus, Bacillus psychrosaccharolyticus and Paenibacillus macquariensis were included in the study for comparison. By arrangement of the strains according to cell wall type, $\mathrm{G}+\mathrm{C}$ content, and biochemical and physiological properties, distinct subgroups were established. Of these, group I A was representative for the species Bacillus insolitus, group II B for Bacillus psychrosaccharolyticus, group II F for Bacillus macquariensis, group III B for Bacillus globisporus and group III C for Bacillus psychrophilus. About a third of the psychrotolerant isolates could not be allocated to any of these groups, nor to any other species of the genus Bacillus or related aerobic spore-forming genera. They formed a number of separate clusters which obviously warrant separate species status.

For the present investigation, the 11 strains of group I (subgroup I A, including the type strain of Bacillus insolitus, DSM $5^{\mathrm{T}}$, and Bacillus insolitus DSM 2272; subgroup I B consisting of isolates $3 \mathrm{H}^{\mathrm{T}}, 71 \mathrm{H} 1,84 \mathrm{E} 1$, $87 \mathrm{H} 2$ and $4 \mathrm{H} 2$; and subgroup I C consisting of isolates $68 \mathrm{E} 3^{\mathrm{T}}, 61 \mathrm{E} 1,4 \mathrm{E} 3$ and $\left.67 \mathrm{E} 1\right)$ were subjected to a number of studies to reveal their taxonomic position.

\section{METHODS}

Bacterial strains. The Bacillus strains used in this study are listed in Table 1. The new isolates were obtained from samples collected in Egypt and Germany in 1985.

Phenotypic characterization. Phenotypic characterization was carried out according to Gordon et al. (1973) with the modification that casein-peptone soymeal-peptone agar (CASO agar; Merck 5458) was used instead of nutrient agar as standard.

Photography. For photomicrographs the cultures were prepared as described by Claus \& Berkeley (1986). Photo- micrographs were taken from cultures grown on CASO agar or Difco marine agar (Difco marine broth 2216 plus agar).

Chemotaxonomic characterization. Composition and structure of peptidoglycan was determined according to Schleifer \& Kandler (1972) and Kandler \& Weiss (1986).

DNA base composition and DNA-DNA hybridization. Determination of base composition was performed as described by Fritze et al. (1990) based on the methods reported by De Ley et al. (1970) and Gillis et al. (1970). DNA hybridizations were performed as described by Spanka \& Fritze (1993).

16S rDNA sequence determination and analyses. Genomic DNA extraction, PCR-mediated amplification of the $16 \mathrm{~S}$ rDNA and purification of PCR products were carried out as described by Rainey et al. (1996). Purified PCR products were sequenced by using the Taq DyeDeoxy Terminator Cycle Sequencing Kit (Applied Biosystems) as directed in the manufacturer's protocol. An Applied Biosystems 373A DNA sequencer was used for the electrophoresis of sequence reaction products. The ae 2 editor (Maidak et al., 1999) was used to align the $16 \mathrm{~S}$ rDNA sequences determined in this study against the $16 \mathrm{~S}$ rDNA sequences of representatives of the main bacterial lineages available from the public databases. Pairwise evolutionary distances were computed by using the correction of Jukes \& Cantor (1969).

\section{RESULTS}

\section{Cell walls}

The diamino acid in position 3 of the peptide side chain of the peptidoglycan of all 11 strains had previously been determined to be ornithine. Accordingly, the strains had been grouped into cell wall group I (Abd El-Rahman, 1988). When these strains (including the type strain of Bacillus insolitus, DSM $5^{\mathrm{T}}$ ) were further analysed for the structure of their peptidoglycan, it was revealed that the peptide side chains were connected through an interpeptide bridge formed by glutamic acid, resulting in an L-Orn-D-Glu cell wall type (A $4 \beta$ type, according to Schleifer \& Kandler, 1972).

Table 1. List of strains investigated in this study

\begin{tabular}{|lccl|}
\hline Name & $\begin{array}{c}\text { G }+ \text { C } \\
(\mathbf{m o l} \%)\end{array}$ & $\begin{array}{c}\text { Physiological } \\
\text { group }\end{array}$ & Source \\
\hline B. insolitus DSM 5 & $35 \cdot 8$ & I A & DSMZ (Larkin \& Stokes, 1967) \\
B. insolitus DSM 2272 & $35 \cdot 7$ & I A & DSMZ (Larkin \& Stokes, 1967) \\
$87 \mathrm{H} 2$ & $36 \cdot 0$ & I B & Water, brook, Lutter, Göttingen, Germany \\
$84 \mathrm{E} 1$ & $36 \cdot 3$ & I B & Water, Weende, Göttingen, Germany \\
3H1 ${ }^{\mathrm{T}}$ (DSM 11706 ${ }^{\mathrm{T}}$ ) & $36 \cdot 5$ & I B & Soil, field, Weende, Göttingen, Germany \\
4H2 & $36 \cdot 6$ & I B & Soil, botanical garden, Göttingen, Germany \\
$71 \mathrm{H} 1$ & $38 \cdot 4$ & I B & Soil, field, Kafr-Hamsa, Kalyobia, Egypt \\
61E1 & $35 \cdot 8$ & I C & Soil, field, Faculty of Agriculture, Shobra \\
& & & Khaima, Cairo, Egypt \\
4E3 & $36 \cdot 3$ & I C & Soil, botanical garden, Göttingen, Germany \\
68E3 ${ }^{\mathrm{T}}$ (DSM 11713 ${ }^{\mathrm{T}}$ ) & $36 \cdot 5$ & I C & Soil, garden, El-Kanater, Egypt \\
67E1 & $36 \cdot 3$ & I C & Soil, field, Shobra Khaima, Cairo, Egypt \\
\hline
\end{tabular}


Table 2. DNA-DNA hybridization of psychrotolerant Bacillus strains of subgroups I A, I B and IC

Each value is the mean of at least two determinations.

\begin{tabular}{|c|c|c|c|c|}
\hline \multirow[t]{2}{*}{ Subgroup } & \multirow[t]{2}{*}{ Strain } & \multicolumn{3}{|c|}{ Percentage DNA-DNA hybridization with: } \\
\hline & & DSM $5^{\mathrm{T}}$ & $87 \mathrm{H} 2$ & $68 \mathrm{E}^{\mathrm{T}}\left(\mathrm{DSM} 11713^{\mathrm{T}}\right)$ \\
\hline I A & DSM $5^{\mathrm{T}}$ & 100 & - & - \\
\hline I A & DSM 2272 & 89 & - & - \\
\hline I B & $87 \mathrm{H} 2$ & 44 & 100 & - \\
\hline I B & 84E1 & 35 & 96 & - \\
\hline I B & $3 \mathrm{H} 1^{\mathrm{T}}\left(\mathrm{DSM} 11706^{\mathrm{T}}\right)$ & 42 & 100 & 44 \\
\hline I B & $4 \mathrm{H} 2$ & 44 & 100 & - \\
\hline I B & $71 \mathrm{H} 1$ & 48 & 71 & - \\
\hline I C & $68 \mathrm{E}^{\mathrm{T}}\left(\mathrm{DSM} 11713^{\mathrm{T}}\right)$ & 53 & - & 100 \\
\hline I C & $4 \mathrm{E} 3$ & 10 & _- & 76 \\
\hline I C & $61 \mathrm{E} 1$ & 55 & 23 & 69 \\
\hline I C & $67 \mathrm{E} 1$ & 57 & 53 & 86 \\
\hline
\end{tabular}

\section{DNA-DNA hybridization}

The DNA of the 11 strains of group I were determined previously to have a $\mathrm{G}+\mathrm{C}$ content of $35 \cdot 7-38.4 \mathrm{~mol} \%$ (Abd El-Rahman, 1988). When the DNAs of these strains were subjected to hybridization studies, three subgroups were found matching the previously established physiological groups I A, I B and I C. Within each group, hybridization values were higher than $70 \%(69 \%$ in one case) and between the groups hybridization values were below $60 \%$ (see Table 2). Group I A consisted of the type strain of Bacillus insolitus (DSM 5 ${ }^{\mathrm{T}}$ ) and one further strain of this species, DSM 2272. Group I B consisted of the isolates $3 \mathrm{H} 1^{\mathrm{T}}, 71 \mathrm{H} 1,84 \mathrm{E} 1,87 \mathrm{H} 2$ and $4 \mathrm{H} 2$. Group I C contained the isolates $68 \mathrm{E}^{\mathrm{T}}, 61 \mathrm{E} 1,4 \mathrm{E} 3$ and $67 \mathrm{E} 1$.

\section{S rDNA sequence analysis}

Of the strains investigated, six were selected for partial 16S rRNA gene sequence determination. Full sequences were determined for strains $3 \mathrm{H}^{\mathrm{T}}$ (DSM $\left.11706^{\mathrm{T}}\right)$ and $68 \mathrm{E} 3^{\mathrm{T}}\left(\mathrm{DSM} 11713^{\mathrm{T}}\right)$. Comparison of the sequences of these strains with reference sequences indicated that both species are members of rRNA group 2 (Ash et al., 1991) in which they form a tight cluster (data not shown). The binary sequence similarity value is $99.8 \%$. The closest relative within this cluster is represented by Bacillus insolitus showing a similarity value of 97.8 or $98.0 \%$. All other species of Bacillus rRNA group 2 are more distantly related, having similarity values $<95 \%$.

\section{Phenotypic characterization}

Nutrient agar or nutrient broth did not support or only weakly supported growth of the psychrotolerant strains. Therefore, all tests were performed on CASO
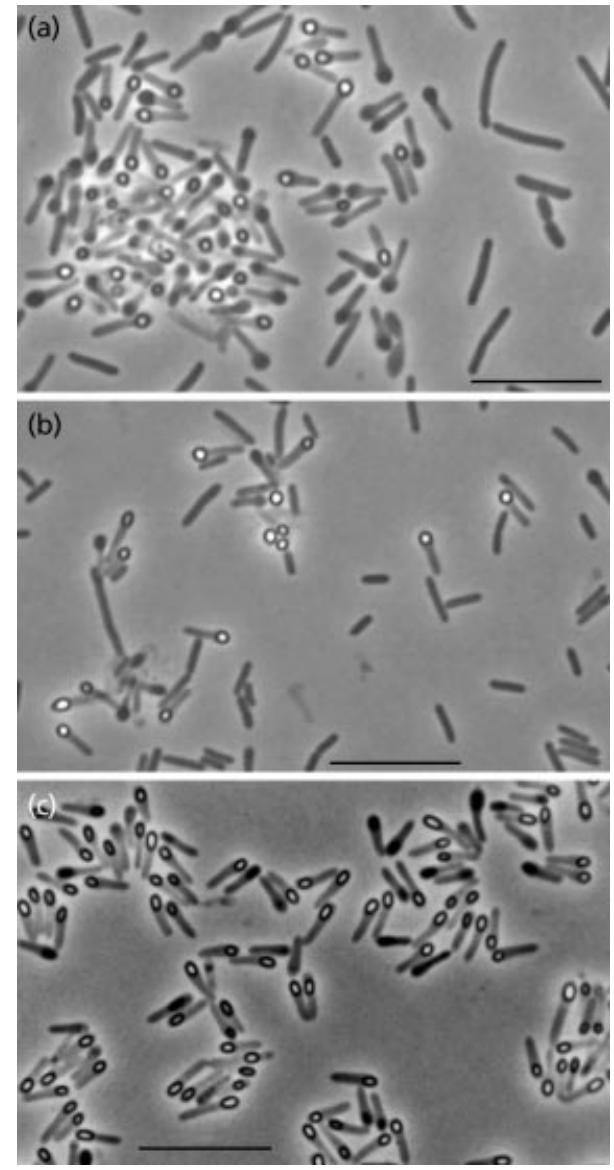

Fig. 1. (a) Bacillus psychrotolerans strain $3 \mathrm{H} 1^{\top}$ (=DSM $11706^{\top}$ ) grown for 3 days on CASO agar (Merck 5458) plus $\mathrm{Mn}^{2+}$ at $26^{\circ} \mathrm{C}$. (b) Bacillus psychrodurans strain $68 \mathrm{E}^{\mathrm{T}}$ (=DSM 11713') grown for 6 days on CASO agar (Merck 5458) plus $\mathrm{Mn}^{2+}$ at $22^{\circ} \mathrm{C}$. (c) Bacillus psychrodurans strain $68 \mathrm{E}^{\mathrm{T}}$ (=DSM $11713^{\mathrm{T}}$ ) grown for 3 days on marine agar (Difco 2216) at $20^{\circ} \mathrm{C}$. Bars, $10 \mu \mathrm{m}$. 
Table 3. Phenotypic characters distinguishing between established groups

+ , Positive; - , negative; \pm , weak; $\mathrm{v}$, variable among strains.

\begin{tabular}{|c|c|c|c|c|c|c|c|c|}
\hline Character & $\begin{array}{c}\text { Group IA } B . \\
\text { insolitus }\end{array}$ & $\begin{array}{c}\text { Group IB } B . \\
\text { psychrotolerans }\end{array}$ & $\begin{array}{c}\text { Group IC } B . \\
\text { psychrodurans }\end{array}$ & B. marimus ${ }^{*}$ & B. globisporus & P. macquariensis & B. psychrophilus & B. psychrosaccharolyticus \\
\hline Sporangium swollen & - & + & + & - & + & + & + & + \\
\hline Reduction of nitrate & - & - & + & $\mathrm{v}$ & - & - & + & + \\
\hline Hydrolysis of starch & - & + & + & - & - & + & - & + \\
\hline Hydrolysis of DNA & - & + & + & $\mathrm{v}$ & + & - & + & + \\
\hline Anaerobic growth with $\mathrm{KNO}_{3} \dagger$ & - & - & + & - & \pm & + & - & - \\
\hline Growth at $3 \% \mathrm{NaCl}$ & - & + & + & + & + & - & + & + \\
\hline Growth at $5 \% \mathrm{NaCl}$ & - & $-(1+)$ & + & $\mathrm{v}$ & - & - & + & - \\
\hline Cell wall & L-Orn-D-Glu & L-Orn-D-Glu & L-Orn-D-Glu & L-Lys-direct & L-Lys-D-Glu: & DAP & L-Lys-D-Gluł: & DAP \\
\hline rRNA group & $2 \S$ & 2 & 2 & 2 & $2 \S$ & $3 \S$ & $2 \S$ & $1 \S$ \\
\hline
\end{tabular}

* Data for B. marinus from Rüger et al. (2000).

$\uparrow$ CASO medium with $0 \cdot 1 \% \mathrm{KNO}_{3}$.

\$ Data for cell wall composition from Stackebrandt et al. (1987).

$\S$ rRNA group allocation from Ash et al. (1991).

agar or in CASO broth (for further details, see Abd ElRahman, 1988).

Spore formation could be induced only for strains DSM 2272, 68E $3^{\mathrm{T}}, 3 \mathrm{H} 1^{\mathrm{T}}, 71 \mathrm{H} 1,84 \mathrm{E} 1$ and $87 \mathrm{H} 2$. Round spores were observed with strains DSM 2272, $68 \mathrm{E} 3^{\mathrm{T}}, 3 \mathrm{H} 1^{\mathrm{T}}, 71 \mathrm{H} 1$ and $87 \mathrm{H} 2$. Strain $3 \mathrm{H} 1^{\mathrm{T}}$ also showed ellipsoid spores and strain 84E1 showed only ellipsoid spores. When strain $68 \mathrm{E}^{\mathrm{T}}$ was grown on Difco marine agar (instead of CASO agar) to enhance spore formation, mainly ellipsoid spores could be observed (Fig. 1). The spores of DSM 2272 did not distend the cell, whereas the spores of strains $3 \mathrm{H}^{\mathrm{T}}$, $71 \mathrm{H} 1,87 \mathrm{H} 2,84 \mathrm{E} 1$ and $68 \mathrm{E}^{3}{ }^{\mathrm{T}}$ did distend the cell.

The lower temperature limit for growth was tested down to $-5^{\circ} \mathrm{C}$. For five strains (DSM $5^{\mathrm{T}}$, DSM 2272, $4 \mathrm{H} 2,3 \mathrm{H} 1^{\mathrm{T}}$ and $4 \mathrm{E} 3$ ) growth was still observed at $-2{ }^{\circ} \mathrm{C}$. Four strains $\left(84 \mathrm{E} 1,61 \mathrm{E} 1,68 \mathrm{E} 3^{\mathrm{T}}\right.$ and $\left.67 \mathrm{E} 1\right)$ were able to grow at $0{ }^{\circ} \mathrm{C}$ and two strains $(71 \mathrm{H} 1$ and $87 \mathrm{H} 2$ ) had their lower growth limit at $+1{ }^{\circ} \mathrm{C}$.

The upper temperature limit for growth was determined to be $25{ }^{\circ} \mathrm{C}$ for one strain (DSM $5^{\mathrm{T}}$ ), $30{ }^{\circ} \mathrm{C}$ for five strains (DSM 2272, 3H $1^{\mathrm{T}}, 68 \mathrm{E} 3^{\mathrm{T}}, 87 \mathrm{H} 2$ and $\left.61 \mathrm{E} 1\right)$, $35^{\circ} \mathrm{C}$ for four strains $(67 \mathrm{E} 1,71 \mathrm{H} 1,4 \mathrm{H} 2$ and $4 \mathrm{E} 3)$ and $40{ }^{\circ} \mathrm{C}$ for one strain (84E1).

Positive reactions for all tested strains (unless indicated otherwise) were found for catalase, oxidase (DSM $5^{\mathrm{T}}$ negative), growth at $+1{ }^{\circ} \mathrm{C}$ and hydrolysis of Tween 20,40 and 60 .

Negative reactions for all tested strains (unless indicated otherwise) were found for $\mathrm{KOH}$ (slightly positive for strains $61 \mathrm{E} 1,67 \mathrm{E} 1$ and $4 \mathrm{H} 2$ ) and aminopeptidase, growth at $40{ }^{\circ} \mathrm{C}$ (84E1 positive), growth in nutrient broth or on nutrient agar (or only very weak and variable growth), growth at $\mathrm{pH} 5 \cdot 7$, growth in the presence of $7 \% \mathrm{NaCl}$, utilization of citrate, hydrolysis of cellulose, hydrolysis of pullulan $(71 \mathrm{H} 1$ positive), hydrolysis of pectin, hydrolysis of chitin, hydrolysis of aesculin in CASO medium, degradation of casein, acid production from arabinose and xylose, the egg yolk lecithinase reaction, production of indole, production of dihydroxyacetone, Voges-Proskauer reaction ( $\mathrm{pH}$ in Voges-Proskauer between 6.2 and 6.8), deamination of phenylalanine, tyrosine degradation, growth in the presence of lysozyme, cleavage of urea and hydrolysis of 4-methyl-umbelliferone glucuronide.

Characters variable within the established groups I A, I B and I C were hydrolysis of gelatin (negative for strains DSM $5^{\mathrm{T}}$, DSM 2272, 3H1 $\left.{ }^{\mathrm{T}}, 4 \mathrm{H} 2,61 \mathrm{E} 1\right)$, hydrolysis of Tween 80 (negative for strains 84E1, $71 \mathrm{H} 1$ and $68 \mathrm{E}^{\mathrm{T}}$ ), acid from glucose (negative for strains DSM 5 ${ }^{\mathrm{T}}$, DSM 2272 and 4H2, weakly positive for strains 4E3, 61E1, 3H1 $\left.{ }^{\mathrm{T}}, 71 \mathrm{H} 1,84 \mathrm{E} 1\right)$, production of acid from mannitol (weakly positive for strains 4E3, $61 \mathrm{E} 1,67 \mathrm{E} 1,68 \mathrm{E} 3^{\mathrm{T}}, 3 \mathrm{H} 1^{\mathrm{T}}$ and $\left.84 \mathrm{E} 1\right)$ and growth in the presence of $5 \% \mathrm{NaCl}$ (positive for strains 84E1, 4E3, $68 \mathrm{E} 3^{\mathrm{T}}$ and $\left.67 \mathrm{E} 1\right)$.

Phenotypic characters varying between the established groups and helping to distinguish between them included the shape of the sporangium, reduction of nitrate, hydrolysis of starch and DNA, anaerobic growth with $\mathrm{KNO}_{3}$ and growth in the presence of $3 \%$ $\mathrm{NaCl}$ (see Table 3).

\section{DISCUSSION}

In a previous evaluation of psychrotolerant Bacillus species and additional psychrotolerant isolates (Abd El-Rahman, 1988), high phenotypic similarity was found between all of these strains. These findings were in accordance with the original descriptions of the hitherto known psychrotolerant Bacillus species. Differentiation at the phenotypic level is especially complicated because of the physiological inactivity of these organisms (Rüger et al., 2000).

Only through the application of a large range of physiological tests has it been possible to establish groups of organisms. A few characters have been 
found to help distinguish among the newly established groups of psychrotolerant Bacillus isolates and between those and the known psychrotolerant Bacillus species. A detailed comparison of phenotypes of groups of psychrotolerant Bacillus is given in Abd ElRahman (1988).

Group I, as defined by Abd El-Rahman (1988), was further evaluated in the present study. Group I A refers to Bacillus insolitus; groups I B and I C refer to two related groups of strains. Characteristic for all strains of group I are their unusual cell walls (L-Orn-DGlu) which distinguish them from all other hitherto validly published aerobic spore-forming species $(B a-$ cillus spp. and relatives).

Physiological and morphological characters that suggested separation of the three groups from each other were the shape of the sporangium, reduction of nitrate, hydrolysis of starch and DNA, anaerobic growth with $\mathrm{KNO}_{3}$ and growth in the presence of $3 \%$ $\mathrm{NaCl}$.

The additional application of DNA-DNA hybridizations for the 11 strains of cell wall group I confirmed the separation of the three groups.

Full 16S rDNA gene sequence analysis of one representative strain of each of groups I B and I C suggested allocation of the organisms to Bacillus rRNA group 2 as established by Ash et al. (1991) and further underlined the novelty of groups I B and I C.

Obviously, Bacillus insolitus and its two neighbouring groups have to be considered as rare species, as, out of a set of 52 isolates and 14 reference strains, only two strains were determined to belong to the species Bacillus insolitus, and five and four strains, respectively, formed the two adjacent groups.

Following the results of the present study it is suggested that the strains of groups I B and I C be recognized as new psychrotolerant species of the genus Bacillus for which the names Bacillus psychrotolerans sp. nov. and Bacillus psychrodurans sp. nov. are proposed, respectively.

The two new species formed by groups I B and I C are easily distinguishable from Bacillus insolitus (group I A) and other psychrophilic aerobic spore-forming organisms by a number of characters (see Table 3 ). The two new species may be distinguished physiologically from each other by their abilities to reduce nitrate, to grow in the presence of $5 \% \mathrm{NaCl}$ and to grow anaerobically in CASO medium with $\mathrm{KNO}_{3}$.

The fact that the genus Bacillus is a large heterogeneous group in need of taxonomic rearrangement has been discussed extensively over the past decades. Recent work has led to the description of more than 20 genera of aerobic endospore-forming bacteria.

It is tempting to follow the trend and designate a new genus for the two new species described in the present study. However, although the cell wall seems to differentiate both species strongly enough from other similar organisms, such single-parameter-based taxa are prone to be unstable and we therefore consider the description of a separate genus as premature. In future studies these two species, together with other organisms of Bacillus rRNA group 2, need to be subjected to a comprehensive polyphasic study to reveal 'good' borderlines between existing genera and potential new ones.

Species descriptions are given below for the strains of groups I B (Bacillus psychrotolerans sp. nov.) and I C (Bacillus psychrodurans sp. nov.).

\section{Description of Bacillus psychrotolerans sp. nov.}

Bacillus psychrotolerans (psy.chro.tol'er.ans. Gr. adj. psychros cold; L. pres. part. tolerans tolerating; N.L. part. adj. psychrotolerans cold-tolerating).

Cells are Gram-positive (according to $\mathrm{KOH}$ and aminopeptidase tests). Cell width, $0 \cdot 4-1 \mu \mathrm{m}$; cell length, $2-7 \mu \mathrm{m}$. Spore formation rare. Spores predominantly round on CASO agar containing $\mathrm{Mn}^{2+}$, located terminally (one of the strains tested did not sporulate). Sporangium swollen. Peptidoglycan type L-Orn-D-Glu (A4 $\beta$ ). The diamino acid in position 3 of the peptidoglycan side chain is ornithine, and glutamic acid forms an interpeptide bridge. Chemoorganotrophic. Does not grow (or only very poorly) in/on nutrient broth or nutrient agar. Good growth in/on CASO broth or agar. Catalase-positive. Oxidase-positive. No anaerobic growth with or without $\mathrm{KNO}_{3}$. Psychrotolerant. Lower temperature limit for growth: $-2^{\circ} \mathrm{C}$ (type strain) up to $1{ }^{\circ} \mathrm{C}$. Upper temperature limit for growth: $30^{\circ} \mathrm{C}$ (type strain) up to $40{ }^{\circ} \mathrm{C}$. No growth in the presence of lysozyme. No growth at $\mathrm{pH} 5 \cdot 7$. Growth at $3 \% \mathrm{NaCl}$; normally no growth at $5 \% \mathrm{NaCl}$ (one of the five strains tested positive); no growth at $7 \% \mathrm{NaCl}$. No tyrosine degradation. DNA degradation positive. No or only weak acid production from D-glucose, L-arabinose, D-xylose and D-mannitol. Hydrolysis of starch. Usually no hydrolysis of pullulan (one of the strains tested positive). No hydrolysis of cellulose. No hydrolysis of pectin. Usually no hydrolysis of gelatin (one of the strains tested positive). No hydrolysis of casein. No hydrolysis of chitin. No hydrolysis of aesculin. Hydrolysis of Tween 20, 40, 60 and usually also of Tween 80 (two of the strains tested negative). No hydrolysis of urea. No hydrolysis of 4-methyl-umbelliferone glucuronide. No citrate hydrolysis. Nitrate not reduced to nitrite. Egg-yolk lecithinase-negative. Phenylalanine not deaminated. Voges-Proskauer reaction negative. $\mathrm{pH}$ in Voges-Proskauer $>6$. Indolenegative. No production of dihydroxyacetone. Type strain is $3 \mathrm{H}^{\mathrm{T}}\left(=\mathrm{DSM} 11706^{\mathrm{T}}=\right.$ NCIMB $\left.13838^{\mathrm{T}}\right)$. Isolated from field soil, Göttingen-Weende, Germany. $\mathrm{G}+\mathrm{C}$ content of the DNA is $36-38 \%(\mathrm{Bd})$ with $36.5 \%$ for the type strain. 


\section{Description of Bacillus psychrodurans sp. nov.}

Bacillus psychrodurans (psy.chro.dur'ans. Gr. adj. psychros cold; L. pres. part. durans enduring; N.L. part. adj. psychrodurans cold-enduring).

Cells are Gram-positive (according to $\mathrm{KOH}$ and aminopeptidase test). Cell width, $0.5-0.6 \mu \mathrm{m}$; cell length, $2-5 \mu \mathrm{m}$. Spore formation rare. Spores predominantly round on CASO agar and predominantly ellipsoid on Difco marine agar; located terminally (spores observed only with type strain). Sporangium swollen. Peptidoglycan type L-Orn-D-Glu (A4 $\beta$ ). The diamino acid in position 3 of the peptidoglycan side chain is ornithine, and glutamic acid forms an interpeptide bridge. Chemo-organotrophic. Does not grow (or only very poorly) in/on nutrient broth or nutrient agar. Good growth in/on CASO broth or agar. Catalase-positive. Oxidase-positive. No anaerobic growth. With $\mathrm{KNO}_{3}$ anaerobic growth positive. Psychrotolerant. Lower temperature limit for growth: $-2{ }^{\circ} \mathrm{C}$ up to $0{ }^{\circ} \mathrm{C}$ (type strain). Upper temperature limit for growth: $30^{\circ} \mathrm{C}$ (type strain) up to $35^{\circ} \mathrm{C}$. No growth in the presence of lysozyme. No growth at $\mathrm{pH} 5 \cdot 7$. Growth at $3 \% \mathrm{NaCl}$ and usually at $5 \% \mathrm{NaCl}$ positive (with $5 \% \mathrm{NaCl}$ one of the four strains tested negative); no growth at $7 \% \mathrm{NaCl}$. No tyrosine degradation. DNA degradation positive. Acid production from D-glucose, L-arabinose, D-xylose and Dmannitol usually negative or only weak (two of the four strains tested, including the type strain, positive with D-glucose and D-mannitol). Hydrolysis of starch. No hydrolysis of pullulan. No hydrolysis of cellulose. No hydrolysis of pectin. Usually hydrolysis of gelatin (one of the four strains tested negative). No hydrolysis of casein. No hydrolysis of chitin. No hydrolysis of aesculin. Hydrolysis of Tween 20, 40, 60 and usually of Tween 80 positive (with Tween 80 type strain negative). No hydrolysis of urea. No hydrolysis of 4-methylumbelliferone glucuronide. No citrate hydrolysis. Nitrate is reduced to nitrite. Egg-yolk lecithinase-negative. Phenylalanine not deaminated. Voges-Proskauer reaction negative. $\mathrm{pH}$ in Voges-Proskauer $>6$. Indole-negative. No production of dihydroxyacetone. Type strain is $68 \mathrm{E}^{\mathrm{T}}\left(=\mathrm{DSM} 11713^{\mathrm{T}}=\mathrm{NCIMB}\right.$ $\left.13837^{\mathrm{T}}\right)$. Isolated from garden soil, El-Kanater, Egypt. $\mathrm{G}+\mathrm{C}$ content of the DNA is $36-37 \mathrm{~mol} \%(\mathrm{Bd})$ with $36.3 \%$ for the type strain.

\section{ACKNOWLEDGEMENTS}

Dr N. Weiss of DSMZ is thanked for structural analysis of cell walls. Ina Kramer (sequencing) and Claudia Wahrenburg (microphotography) are thanked for excellent technical assistance.

\section{REFERENCES}

Abd El-Rahman, H. A. (1988). Taxonomische Untersuchungen an psychrotrophen Bacillus-Stämmen. Doctorate thesis, University of Göttingen, Germany.

Ash, C., Farrow, J. A. E., Wallbanks, S. \& Collins, M. D. (1991). Phylogenetic heterogeneity of the genus Bacillus revealed by com- parative analysis of small-subunit-ribosomal RNA sequences. Lett Appl Microbiol 13, 202-206.

Ash, C., Priest, F. G. \& Collins, M. D. (1993). Molecular identification of rRNA group 3 bacilli (Ash, Farrow, Wallbanks and Collins) using a PCR probe test. Proposal for the creation of a new genus Paenibacillus. Antonie van Leeuwenhoek 64, 253-260.

Claus, D. \& Berkeley, R. C. W. (1986). Genus Bacillus Cohn 1872, $174^{\mathrm{AL}}$. In Bergey's Manual of Systematic Bacteriology, vol. 2, pp. 1105-1139. Edited by P. H. A. Sneath, N. S. Mair, M. E. Sharpe \& J. G. Holt. Baltimore: Williams \& Wilkins.

De Ley, J., Cattoir, H. \& Reynaerts, A. (1970). The quantitative measurement of DNA hybridization from renaturation rates. Eur $J$ Biochem 12, 133-142.

Farrow, J. A., Wallbanks, S. \& Collins, M. D. (1994). Phylogenetic interrelationship of round-spore-forming bacilli containing cell walls based on lysine and the non-spore-forming genera Caryophanon, Exiguobacterium, Kurthia, and Planococcus. Int J Syst Bacteriol 44, 74-82; erratum 377.

Fox, G. E., Wisotzkey, J. D. \& Jurtshuk, P., Jr (1992). How close is close: $16 \mathrm{~S}$ rRNA sequence identity may not be sufficient to guarantee species identity. Int J Syst Bacteriol 42, 166-170.

Fritze, D., Flossdorf, J. \& Claus, D. (1990). Taxonomy of alkaliphilic Bacillus strains. Int J Syst Bacteriol 40, 92-97.

Gillis, M., De Ley, J. \& De Cleene, M. (1970). The determination of molecular weight of bacterial genome DNA from renaturation rates. Eur J Biochem 12, 143-153.

Gordon, R. E., Haynes, W. C. \& Pang, C. H. (1973). The Genus Bacillus. Agricultural Handbook No. 427. Washington, DC: US Department of Agriculture.

Jukes, T. H. \& Cantor, C. R. (1969). Evolution of protein molecules. In Mammalian Protein Metabolism, pp. 21-132. Edited by H. N. Munro. New York: Academic Press.

Kandler, O. \& Weiss, N. (1986). Genus Lactobacillus Beijerinck 1901, $212^{\mathrm{AL}}$. In Bergey's Manual of Systematic Bacteriology, vol. 2, pp. 1209-1219. Edited by P. H. A. Sneath, N. S. Mair, M. E. Sharpe \& J. G. Holt. Baltimore: Williams \& Wilkins.

Larkin, J. M. \& Stokes, J. L. (1967). Taxonomy of psychrophilic strains of Bacillus. J Bacteriol 94, 889-895.

Maidak, B. L., Cole, J. R., Parker, C. T., Jr \& 11 other authors (1999). A new version of the RDP (Ribosomal Database Project). Nucleic Acids Res 27, 171-173.

Marshall, B. J. \& Ohye, D. F. (1966). Bacillus macquariensis n. sp., a psychrotrophic bacterium from sub-Antarctic soil. J Gen Microbiol 44, 41-46.

Nakamura, L. K. (1984). Bacillus psychrophilus sp. nov., nom. rev. Int J Syst Bacteriol 34, 121-123.

Priest, F. G., Goodfellow, M. \& Todd, C. (1988). A numerical classification of the genus Bacillus. J Gen Microbiol 134, 1847-1882.

Rainey, F. A., Ward-Rainey, N., Kroppenstedt, R. M. \& Stackebrandt, E. (1996). The genus Nocardiopsis represents a phylogenetically coherent taxon and a distinct actinomycete lineage: proposal of Nocardiopsaceae fam. nov. Int J Syst Bacteriol 46, 1088-1092.

Rüger, H.-J. (1983). Differentiation of Bacillus globisporus, Bacillus marinus comb. nov., Bacillus aminovorans and Bacillus insolitus. Int $J$ Syst Bacteriol 33, 157-161.

Rüger, H.-J. \& Richter, G. (1979). Bacillus globisporus subsp. marinus subsp. nov. Int J Syst Bacteriol 29, 196-203.

Rüger, H.-J., Fritze, D. \& Spröer, C. (2000). New psychrophilic and psychrotolerant Bacillus marinus strains from tropical and polar deepsea sediments and emended description of the species. Int J Syst Evol Microbiol 50, 1305-1313.

Schleifer, K. H. \& Kandler, O. (1972). Peptidoglycan types of bacterial cell walls and their taxonomic implications. Bacteriol Rev 36, 407-477.

Spanka, R. \& Fritze, D. (1993). Bacillus cohnii sp. nov., a new, obligately alkaliphilic, oval spore forming Bacillus species with ornithine and aspartic acid instead of diaminopimelic acid in the cell wall. Int J Syst Bacteriol 43, 150-156. 
Stackebrandt, E., Ludwig, W., Weizenegger, M., Dorn, S., McGill, T. J., Fox, G. E., Woese, C. R., Schubert, W. \& Schleifer, K.-H. (1987). Comparative 16S rRNA oligonucleotide analysis and murein types of round-spore-forming bacilli and non-spore-forming relatives. J Gen Microbiol 133, 2523-2529.

Yoon, J.-H., Lee, K.-C., Weiss, N., Kho, Y. H., Kang, K. H. \& Park, Y.-H. (2001a). Sporosarcina aquimarina sp. nov., a bacterium isolated from seawater in Korea, and transfer of Bacillus globisporus (Larkin and Stokes 1967), Bacillus psychrophilus (Nakamura 1984) and Bacillus pasteurii (Chester 1898) to the genus Sporosarcina as Sporosarcina globispora comb. nov., Sporosarcina psychrophila comb. nov. and Sporosarcina pasteurii comb. nov., and emended description of the genus Sporosarcina. Int J Syst Evol Microbiol 51, 1079-1086.

Yoon, J.-H., Weiss, N., Lee, K.-C., Lee, I.-S., Kang, K. H. \& Park, Y.-H. (2001b). Jeotgalibacillus alimentarius gen. nov., sp. nov., a novel bacterium isolated from jeotgal with L-lysine in the cell wall, and reclassification of Bacillus marinus Rüger 1983 as Marinibacillus marinus gen. nov., comb. nov. Int J Syst Evol Microbiol 51, 1087-1093. 